IRA-International Journal of Management \&

Social Sciences

ISSN 2455-2267; Vol.11, Issue 03 (June 2018)

Pg. no. 108-117.

Institute of Research Advances

http://research-advances.org/index.php/RAJMSS

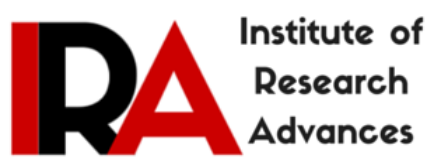

\title{
A Study of Causes of Stress and Stress Management among Youth
}

\author{
Dr. Deepti Bhargava ${ }^{1 \#} \&$ Hemant Trivedi ${ }^{2}$ \\ ${ }^{1}$ Head, Department of Management Studies, Shrinathji Institute of Technology \& Engineering, Nathdwara, \\ Rajsamand, Rajasthan, India. \\ ${ }^{2}$ Research and Adjunct Faculty, Pacific Academy of Higher Education and Research, Udaipur, India. \\ \#corresponding author. \\ Type of Review: Peer Reviewed. \\ DOI: http://dx.doi.org/10.21013/jmss.v11.n3.p1
}

How to cite this paper:

Bhargava, D., Trivedi, H. (2018). A Study of Causes of Stress and Stress Management among Youth. IRAInternational Journal of Management \& Social Sciences (ISSN 2455-2267), 11(3), 108-117. doi:http://dx.doi.org/10.21013/jmss.v11.n3.p1

(C) Institute of Research Advances.

\section{(c)) BY-NC}

This work is licensed under a Creative Commons Attribution-Non Commercial 4.0 International License subject to proper citation to the publication source of the work.

Disclaimer: The scholarly papers as reviewed and published by the Institute of Research Advances (IRA) are the views and opinions of their respective authors and are not the views or opinions of the IRA. The IRA disclaims of any harm or loss caused due to the published content to any party.

Institute of Research Advances is an institutional publisher member of Publishers Inter Linking Association Inc. (PILA-CrossRef), USA. The institute is an institutional signatory to the Budapest Open Access Initiative, Hungary advocating the open access of scientific and scholarly knowledge. The Institute is a registered content provider under Open Access Initiative Protocol for Metadata Harvesting (OAI-PMH).

The journal is indexed \& included in WorldCat Discovery Service (USA), CrossRef Metadata Search (USA), WorldCat (USA), OCLC (USA), Open J-Gate (India), EZB (Germany) Scilit (Switzerland), Airiti (China), Bielefeld Academic Search Engine (BASE) of Bielefeld University, Germany, PKP Index of Simon Fraser University, Canada. 


\begin{abstract}
Stress is a condition of mental pressure for particular individual facing problems from environmental and social well-being which leads to so many diseases. Young age is the critical period because at this time youth faces lots of changes in his/her life. They are expected to be the elites in the society. Thus, they should enhance their stress management abilities so as to live a healthy life after entering the society. When a child enters into the youth age, they need to not only adapt themselves to the new life and new environment but also be familiar with many new people, events, and things. The life stress on them is considerable. Therefore, understanding the sources of stress among them and how they can cope with the stress is very important. The researcher found that the stress mainly comes from academic tests, interpersonal relations, relationship problems, life changes, and career exploration. Such stress may usually cause psychological, physical, and behavioral problems. This study finds the causes of stress among youth. So after identifying causes the researcher suggests that more emphasis can be given to development stage of child into adolescence. They should be brought up in the positive environment. More emphasis should be given to the outdoor activities and create hostile learning environment by minimizing the negative impact of stressors. The findings will help the individual students, scholars, lecturers, career and counseling centers.
\end{abstract}

Keywords: Stress, Symptoms, Stressor, Youth

\title{
INTRODUCTION
}

Selye (1956) defines stress as "any external event or any internal drive which threaten to upset the organism equilibrium is stress". Stress is a condition or feeling experienced when a person perceives that demands exceed the personal and social resources the individual is able to mobilize.

In the present competitive age it is reported that young generation are found to be more in stress. We got the information related to depression, attempt to suicide and some psychological symptoms among the youth. Sometime we got the information related to suicide, attempted suicide depression, dropout and many more psychological symptoms among the youth. Now scenario has been changing most of us aware about the stressor which affect the college students and maintain the environment which induces the positive thinking among youth. The measures have also taken by the individuals and different organization to conduct the various programs to reduce the stress.

Adolescence is a dangerous period of time where young people experience self organization and role confusion. For them, stress mainly comes from academic tests, interpersonal relations, relationship problems, financial, and career exploration. Such stress may usually cause psychological, physical, and behavioral problems. Taking all these factors into account an effort is made to understand the stress and emotional adjustments of today's youth. The inference of this study may lead to better adjustment and academic performance of the students.

\section{LITERATURE REVIEW}

There have been many studies (Schafer, 1996; Fisher, 1994; Altmaier, 1983; Greenberg \& Valletutti, 1980), which have reported strong relationship between stress and college students. According to Lazarus \& Folkman (1984), stress is a mental or physical phenomenon formed through one's cognitive appraisal of the stimulation and is a result of one's interaction with the environment. The existence of stress depends on the existence of the stressor. Feng (1992) and Volpe (2000) defined stressor as anything that challenges an individual's adaptability or stimulates an individual's body or mentality. Stress can be caused by environmental factors, psychological factors, biological factors, and social factors.

Academic stress among students have long been researched on, and researchers have identified stressors as too many assignments, competition with other students, failures, lack of pocket money (Fairbrother and Warn, 2003), poor relationships with other students or lecturers, family or problems at home. Institutional (university) level stressors are overcrowded lecture halls, (Ongori, 2007; Awino and Agolla, 2008), semester system, and inadequate resources to perform academic work. Erkutlu and Chafra (2006) for instance opines that, when these events take place, an individual becomes disorganised, disoriented and therefore less able to cope up, thus resulting in stress related health problems. The pressure to perform well in the examination or test and time allocated makes academic environment 
very stressful (Erkutlu and Chafra, 2006; Polychronopoulou and Divaris, 2005; Misra and McKean, 2000). This is likely to affect the social relations both within the University and outside (Fairbrother and Warn, 2004) since there is conflict with the social aspect of one life.

Researchers (Malach Pines and Keinan, 2007; Ongori, 2007; Ongori and Agolla, 2008; Agolla, 2009) have long identified stress symptoms as lack of energy, taking over the counter medication, high blood pressure, feeling depresssed, increase in appetite, trouble concentrating, restlessness, tensions and anxiety among others. An individual experiencing one of these factors is likely to be a victim of stress. Although this may also depend on how the individual appraises the situation, and how resilient is the person. While the negative effects of stress on an individual may vary considerably from one student based on their previous encounter with situations and the resilient of the individual student. In their findings (Jaramillo et al., 2005; Stevenson and Harper, 2006) point out that, the perception of the individual determines whether or not the stressor has a detrimental effect; that is whether it causes physical or psychological symptoms of stress in the individual.

Another reason why little have been done on students stress could be due to the fact that students' presence in the institution have no direct relationship to the quality of education they get. We argue that, unless the university puts appropriate measures that take care of well being of the students, the student's health may compromise the quality of education they are supposed to get (Daniels and Harris, 2000; Smith et al., 2000; Finlayson, 2003). Gibbons and Gibbons (2007) and McCarty et al. (2007) have carried out extensive research on stress and found out that, stress is associated with how an individual appraises situations and the coping strategies adopted.

\section{CAUSES OF STRESS AMONG STUDENTS}

The events that provoke stress are called stressors, and they cover a whole range of situations - everything from outright physical danger to making a class presentation or taking a semester's worth of your toughest subject. Some of the main stressor among students are:

Academics-The worry about academic performance can cause stress symptoms such as anxiety, insomnia or changes in your appetite and overall mood. According to Morehouse State University, youth have poor study habits and cram last minute studying in the night before exams. The fear of exams and workload create stress among students. The first cause of stress among university students is a lot of assignments.

Finances - All young people feel stress about money! Most young people do not have jobs, or the jobs that they do have don't pay as much as they would like for them to. They want to maintain the lifestyle and fulfill the demand of articles like mobile, bikes and cars etc. If they fail to fulfill the requirement then it creates a stress.

Relationships - Relationships are another big aspect of stress. Everyone wants to have friends, whether they are close friends or just acquaintances. If a person finds that making friends is a bit harder than he/ she had expected, stress is present here as well.

Career- Job Stress is a chronic disease caused among the current youth that negatively affect an individual's performance and/or overall well-being of his body and mind. The high competition, an inconsiderate work colleague, a lack of job security, there are many causes of job stress. The students have fear of not getting the job opportunity and competition in the market.

Time Management-A lack of time management also causes stress on youth, whether secondary or tertiary. Balancing academics, peer activities, and home life can be difficult. Toss in a part-time job and the challenge increases.

\section{RESEARCH METHODOLOGY}

The tool employed for generating responses was questionnaire based survey of young candidates who are students or some are working under different organization. The Information was collected from both primary and secondary data. 


\section{OBJECTIVES OF THE STUDY}

$\checkmark$ To study the symptoms of stress among Youth.

$\checkmark$ To measure the level of stress among the Youth.

$\checkmark$ To know the strategies to cope up with stressor by the Youth.

\section{RESEARCH DESIGN}

The sample is collected from the young male and female from the area Rajasthan, Punjab, Uttarpradesh and Gujarat region of India on random basis. The questionnaire was distributed among 300 young people and got 225 responses.

\section{Tools for data collection}

A questionnaire is designed with the three sections. One section highlights the symptoms of stress, second section highlights the stressor and third section highlights the coping strategies used by the Youth. In order to achieve the objective both primary and secondary sources of information are relied upon. The primary data was collected through structured questionnaires apart from discussions with students.

\section{Data Collection:}

Data Sources:

(i) Secondary Data through Internet, Magazine, Journals, Books etc

(ii) Primary Data through Questionnaire

(iii) Contact Method

(iv) Personal Interaction

The questionnaire has main three parts, first part covers the different symptoms on a seven point scale, second part covers the causes of stress through 25 statements on five point scale and last section covers the ten coping strategies.

\section{DATA ANALYSIS AND INTERPRETATION}

The respondents are from the different areas of north India, some are working and some are doing studies. The table shows that total numbers of respondent were 225.The maximum respondent belong from the age group 21-23 years ie. $39.11 \%, 23-24$ represents $51 \%$, up to $20 \mathrm{yrs}$ represents and $18.18 \%$ from >23years. The male respondents are 135 and female are 90. Maximum respondent are from the income level of 10000 to 20000/. Respondent are from the environment where single parent working.

Table 1: Distribution According to Age

\begin{tabular}{|c|c|c|}
\hline Age & N & \% \\
\hline Up to 20 years & 56 & 24.89 \\
\hline 21-22 years & 88 & 39.11 \\
\hline 23-24 years & 51 & 22.67 \\
\hline Above 25 years & 25 & 11.11 \\
\hline No Response & 5 & 2.22 \\
\hline Total & $\mathbf{2 2 5}$ & $\mathbf{1 0 0 . 0 0}$ \\
\hline
\end{tabular}

Table 2: Distribution According to Gender

\begin{tabular}{|c|c|c|}
\hline Gender & N & \% \\
\hline Male & 135 & 60.00 \\
\hline Female & 90 & 40.00 \\
\hline Total & $\mathbf{2 2 5}$ & $\mathbf{1 0 0 . 0 0}$ \\
\hline
\end{tabular}


Table 3: Monthly Income (Family) wise Distribution

\begin{tabular}{|c|c|c|}
\hline Income & N & \% \\
\hline Up to Rs. 10000 & 37 & 16.44 \\
\hline Rs. 10,0001 - Rs. 20,000 & 51 & 22.67 \\
\hline Rs. 20,0001 - Rs. 30,000 & 39 & 17.33 \\
\hline Rs. 30,0001 - Rs. 40,000 & 26 & 11.56 \\
\hline Rs. 50000 and Above & 29 & 12.89 \\
\hline No Response & 43 & 19.11 \\
\hline Total & $\mathbf{2 2 5}$ & $\mathbf{1 0 0 . 0 0}$ \\
\hline
\end{tabular}

The table shows the working status of parents, 14.22 respondents parents are working whereas 85.78 has single working parent.

Table 4: Distribution According to Working Status of Mother

\begin{tabular}{|l|c|c|}
\hline Working Status of Parents & N & \% \\
\hline Mother - Father Both Working & 32 & 14.22 \\
\hline Father Working & 193 & 85.78 \\
\hline Total & $\mathbf{2 2 5}$ & $\mathbf{1 0 0 . 0 0}$ \\
\hline
\end{tabular}

\section{Stress Symptoms among youth}

The result indicates that students do experience stress and symptoms as shown in Table 3 below. The highest percentage is $81.60 \%$ suffering from depression followed by Insomnia (79.82\%) and bad eating habit (78.22\%). It is observed that most of the youth suffering from depression, tension etc. The lifestyle of youth consist of various desires, they want to fulfill the desires and if they are not capable to fulfill the wishes they feel somewhat stress. The levels of symptoms are toward high. Youngsters may be unable to concentrate on academics and sports. They isolate from family activities or peer relationships. Adolescents may be experimenting with drugs and alcohol. They may have poor appetite and low immunity.

Table 5: Symptoms

\begin{tabular}{|l|c|c|}
\hline \multicolumn{1}{|c|}{ Symptoms } & \% & Rank \\
\hline Headaches & 71.29 & 8 \\
\hline Tense muscles, sore neck and back & 74.93 & 5 \\
\hline Fatigue & 73.60 & 7 \\
\hline Anxiety, worry, phobias & 67.20 & 10 \\
\hline Insomnia & $\mathbf{7 9 . 8 2}$ & $\mathbf{2}$ \\
\hline Irritability & 70.84 & 9 \\
\hline Bouts of anger & 64.18 & 11 \\
\hline Boredom, Depression & $\mathbf{7 8 . 2 2}$ & $\mathbf{3}$ \\
\hline Binge eating & $\mathbf{8 1 . 6 0}$ & $\mathbf{1}$ \\
\hline Constipation & 75.38 & 4 \\
\hline Restlessness & 73.69 & 6 \\
\hline
\end{tabular}




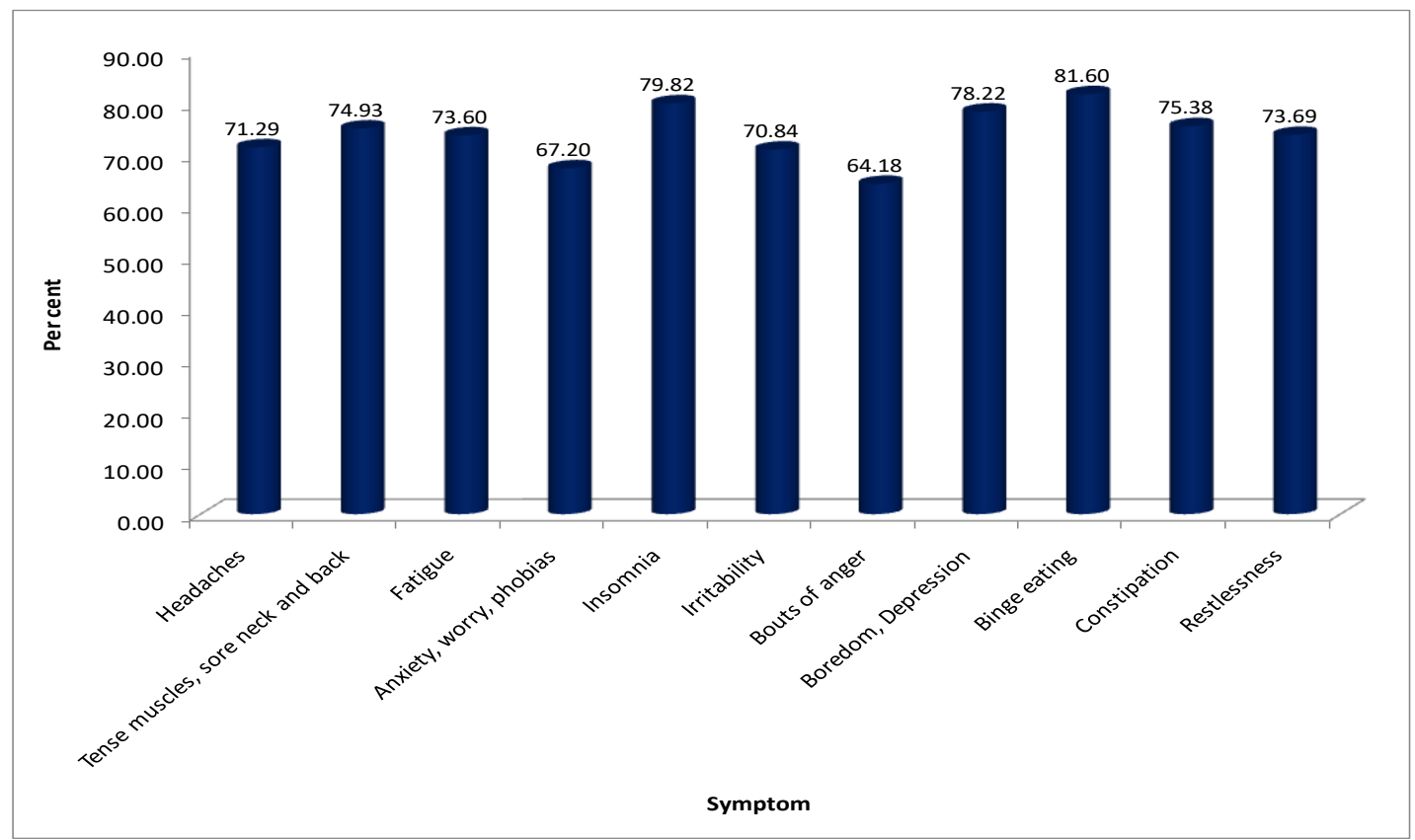

Graph: 1-Stress symptoms

\section{Causes of Stress}

The first part of the questionnaire indicates the factor academics which show the stress level $61.81 \%$ whereas highest level of stress generates due to relationship. It is observed that due to the increasing use of social media the relationship stress increasing. The other stressor psychological factors have $73.40 \%$, young generation have $72.55 \%$ of financial stress and 68.395 having career stress.

The $\%$ of all stressor are high it means to maintain the life style

Table 6: Level of Stress of each kind

\begin{tabular}{|l|c|c|}
\hline \multicolumn{1}{|c|}{ Kind of Stress } & $\begin{array}{c}\text { Level of Stress } \\
(\boldsymbol{\%})\end{array}$ & Rank \\
\hline Academics & 61.81 & 5 \\
\hline Financial or Economic Stress & 72.55 & 3 \\
\hline Relationship Stress & 74.74 & 1 \\
\hline Future / Career Growth Stress & 68.39 & 4 \\
\hline Psychological Stress & 73.40 & 2 \\
\hline \multicolumn{1}{|c|}{ Overall Stress } & $\mathbf{2 0 . 1 8}$ \\
\cline { 2 - 3 } & \multicolumn{2}{|c|}{} \\
\hline
\end{tabular}




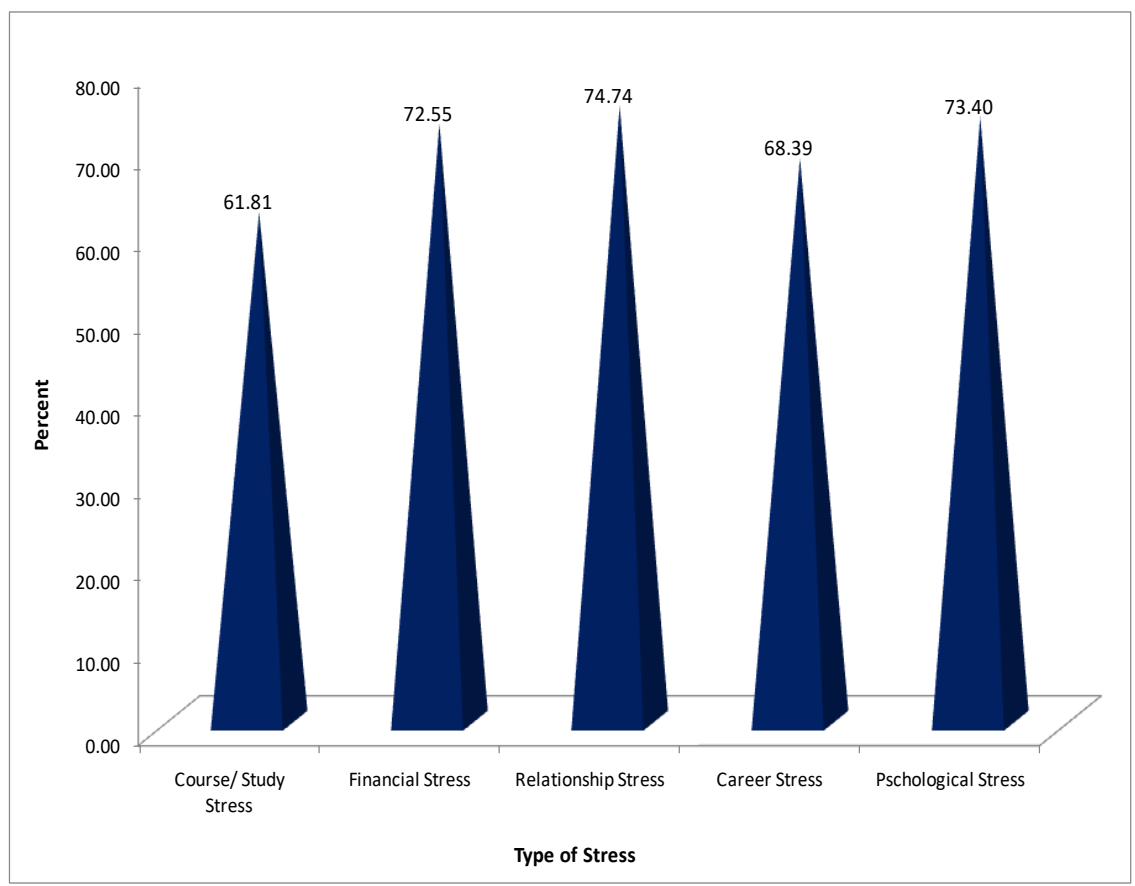

Graph:2-Level of stress

\section{Coping Strategies}

The different strategies used by the students to maintain the stress level according to students are:

$\checkmark$ Most of the students want to make friends (80.89\%)

$\checkmark$ Students want to become live on social networking sites to cope up with stress (76.00\%)

$\checkmark$ Students want to talk with family members to cope up with family members (74.67\%)

$\checkmark \quad$ Other strategies are watch movies, play games and use internet.

Table 7: Activity to Reduce Stress

\begin{tabular}{|l|c|c|c|}
\hline \multicolumn{1}{|c|}{ Action } & N & \% & Rank \\
\hline Watch movie with friends & 150 & 66.67 & 4 \\
\hline Play Games & 139 & 61.78 & 5 \\
\hline Talk with friend(s) & 182 & 80.89 & 1 \\
\hline Talk to family member(s) & 168 & 74.67 & 3 \\
\hline Go to picnic/excursions & 75 & 33.33 & 10 \\
\hline Use Internet (Social networking sites - Facebook, & 171 & 76.00 & 2 \\
\hline Google+ etc.) or other sites & 137 & 60.89 & 6 \\
\hline Listen Music & 92 & 40.89 & 7 \\
\hline Do exercise / yoga & 77 & 34.22 & 9 \\
\hline Read self help books & 83 & 36.89 & 8 \\
\hline Attend cultural programmes & & & \\
\hline
\end{tabular}




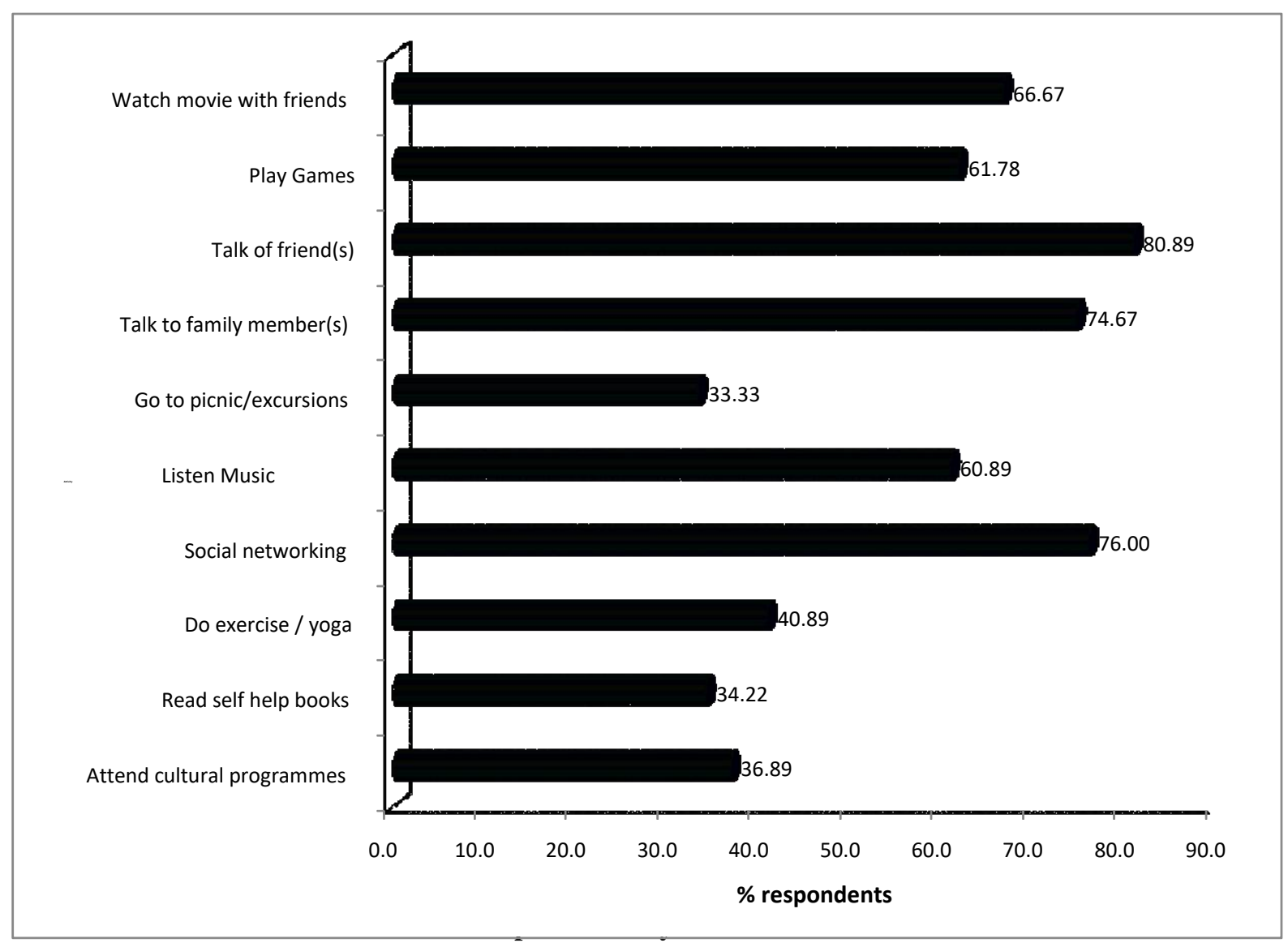

\section{Hypothesis Testing}

To test the significant level between age and stress $\mathrm{F}$ test is applied. The non significant result is occurred between the different age group. It shows that the all age group of youth have same factors of stress. There is overall non significant relationship exist between different age group.

Table 7:Age and Stress

\begin{tabular}{|c|c|c|c|c|c|c|}
\hline Age & N & Mean & SD & F & df & Result \\
\cline { 1 - 4 } Up to 20 years & 56 & 3.57 & 0.66 & & & \\
\cline { 1 - 4 } 21-22 years & 88 & 3.47 & 0.58 & \multirow{2}{*}{0.518} & \multirow{2}{*}{3,216} & $\begin{array}{c}\text { NS }(\mathrm{p}> \\
0.05)\end{array}$ \\
\cline { 1 - 4 } 23-24 years & 51 & 3.54 & 0.65 & & \\
\hline Above 25 years & 25 & 3.43 & 0.51 & & \\
\hline
\end{tabular}

To test the significant level between income level and stress $\mathrm{F}$ test is applied. The significant result is occurred between the different income group. It means income affect the level of stress. There is overall significant relationship exist between different income groups. 
Table 8: Income and Stress

\begin{tabular}{|c|c|c|c|c|c|c|}
\hline Income & $\mathbf{N}$ & Mean & SD & $\mathbf{F}$ & df & Result \\
\hline Up to Rs. 10000 & 37 & 3.55 & 0.47 & \multirow{5}{*}{8.611} & \multirow{5}{*}{4,177} & \multirow{5}{*}{$\begin{array}{c}* * *(\mathrm{p}< \\
0.001)\end{array}$} \\
\hline Rs. 10,0001 - Rs. 20,000 & 51 & 3.10 & 0.41 & & & \\
\hline Rs. 20,0001 - Rs. 30,000 & 39 & 3.41 & 0.47 & & & \\
\hline Rs. 30,0001 - Rs. 40,000 & 26 & 3.82 & 1.00 & & & \\
\hline Rs. 50000 and Above & 29 & 3.50 & 0.37 & & & \\
\hline
\end{tabular}

To test the significant level between working pattern of parents and stress $\mathrm{F}$ test is applied. The significant result is occurred between the parents working pattern. This is due when both father and mother are working children's not getting so much time to discuss their problems and it create stress. There is overall significant relationship exist between different income groups.

Table 9: Working Status of Parents and Stress

\begin{tabular}{|c|c|c|c|c|c|}
\hline $\begin{array}{c}\text { Working Status of } \\
\text { Parents }\end{array}$ & N & Mean & SD & Z & Result \\
\hline $\begin{array}{c}\text { Mother - Father Both } \\
\text { Working }\end{array}$ & 32 & 3.85 & 0.67 & 3.557 & $\begin{array}{c}* * *(\mathrm{p}< \\
0.001)\end{array}$ \\
\hline Single Parent is Working & 193 & 3.45 & 0.57 & & \\
\hline
\end{tabular}

\section{SUGGESTIONS}

The future of any nation lies heavily on the young people since they are the tomorrow's leaders; therefore, it is important to identify the causes, symptoms, and the consequences of stress on students. The negative effect of stress on youth is likely to pose challenge to the individual, their colleagues, and the society as a whole (Siegrist, 1998; Cartwright and Boyes, 2000). Stress poses a great threat to quality of life for youth (Danna and Griffin, 1999; Dyck, 2001). Some of the suggestions to reduce the stress among youth are:

$>$ Workshops to beat stress along with lectures motivating a positive lifestyle have become part of the academic curriculum, so that youngsters are being inspired to live a healthy life. Workshops play an important role as they help an individual realize their inner strength.

$>$ Set personal and professional objective.

$>$ Keep them organized and planned.

$>$ Time management

$>$ Up-to-date the course work

$>$ Get involved with various activities.

$>$ Maintain communication with family.

$>$ Form healthy relationships.

$>$ Share views and problems with someone.

$>$ Get to know belongings.

$>$ Positive thinking

$>$ Adolescents should develop competencies (academic, social, life skills)

$>$ Adolescents should take good nutritional food and exercise regularly 
Adolescents should take time out to relax or to do recreational activities. $\neg$ Adolescents should develop hobbies.

\section{CONCLUSION}

From the findings, the results clearly show that youth are stressed toward high level. The symptoms identified are being eating, depression and headaches are more among students. It is identified that among all factors, the main causes of stress among youth is relationship stress, financial and psychological stress. They want to maintain the social network and they are increasing the networking with the use of technology. The next stress they are feeling is career related. They have fear of job opportunity and how they survive in the competitive environment. Young respondents were able to identify some strategies to cope with stress such as meditation, enough sleeping, going out with the friends and counseling.

It is observed that due to the increase us of social media the young generation become self centered and only connect with the technology. It reduces the physical movement of the body and spending time with relatives and friends. All these create stress which increases the case of depression and suicide. It is necessary and suggestions to the young people that make objective planned systematically, use technology within limit and share your emotions with your loved ones.

\section{REFERENCES}

[1]. A Singh, S. Singh, Stress and adjustment among professional and non-professional students, Industrial Psychiatry journal, 2008.

[2]. Banu Sayiner, Stress Level Of University Students, stanbul Ticaret Üniversitesi,_stanbul2006

[3]. Lisa Schneider, Perceived Stress among Engineering Students, Cornell University,2002

[4]. Denise Pfeiffer, Academic And Environmental Stress Among Undergraduate And Graduate College Students: A Literature Review, The Graduate School University Of Wisconsin-Stout December, 2001

[5]. Joseph E. Agolla and Henry Ongori, An assessment of academic stress among undergraduate students: The case of University of Botswana, Educational Research and Review Vol. 4 (2), pp. 063-070, February 2009 Available online at ISSN 1990-3839 @ 2009 Academic Journals

[6]. Redhwan AANa, Sami ARa, Karim AJa, Chan Rb and Zaleha MI, Stress and Coping Strategies among Management and Science University Students: A Qualitative Study, iiumedic.pdf 